\title{
Perception of cocoa farmers to voluntary standard certification: An implication on Cocoa Transformation in Nigeria
}

\author{
Agbongiarhuoyi Anthony Eghe ${ }^{1}$., Osun Taiwo ${ }^{2}$., Famuyiwa Busayo Solomon ${ }^{3}$., \\ Oseni, Joseph Olumide ${ }^{4}$ \\ 1.\&3. Farming Systems Research and Extension, Cocoa Research Institute of Nigeria, PMB 5244, Ibadan, Nigeria \\ 2. Institute of Food Economics and Consumption Studies, University of Kiel, Olshausenstraße 40, 24098 Kiel, \\ Germany \\ 4. Department of Agricultural and Resource Economics, Federal University of Technology PMB 704 Akure, \\ Ondo State Nigeria
}

\begin{abstract}
The study examined the perception and socio-economic variables of farmers about cocoa certification in some selected States in Nigeria. Purposive sampling technique was used to select 80 farmers in Cross River and Osun States due to their exposure to cocoa certification. Structured interview schedule was used to collect field data. Descriptive statistics and correlation were used for analyses. Majority (87.5\%) were aware of voluntary standard cocoa certification notably Rainforest Alliance and UTZ. However, $32.5 \%$ of the farmers claimed to have received certification training from some exporters who used UTZ label. Many of the farmers (67.5\%) believed that the Cocoa Transformation Agenda (CocTA) of Government will encourage them to practice certification. More farmers (52.5\%) had low perception towards cocoa certification. Results revealed that socio-economic characteristics: age (-0.37), farming experience (-0.31), farm size (0.36) and yield (0.24) at probability $<0.05$ had significant influence on the perception of farmers. From the study, socioeconomic variables had reasonable influence on farmers' perception of cocoa certification. It implies that these are relevant factors which CocTA and other stakeholders can explore to ensure sustainable cocoa production. Training of more farmers on cocoa certification in the study areas is advocated to consolidate their knowledge and practice.
\end{abstract}

Keywords: Perception, cocoa farmers, Voluntary standard certification, Socio-economic characteristics

\section{Introduction}

Cocoa is an important commodity crop which is consumed by majority of people across the globe. It has many health benefits and contributes significantly to the gross domestic product (GDP) of producing countries. In attempt to ensure continuous production of quality beans, there have been calls to certify cocoa beans from farmers so that consumers can be sure of the products made from the crop; hence, the need for voluntary standard certification. Voluntary standard is a standard developed by Non-Governmental Organizations (NGOs) which is not-for-profit making.

Certification is a process of assessing compliance to the standard set by a particular organization. Examples of certification schemes include: UTZ certified, Rainforest Alliance, Fairtrade, Organic, Global G.A.P. and CAFÉ Practices (Paschall and Seville 2012 and Hafid.,et al 2013).

In Nigeria the UTZ certified through solidaridad carried out the first cocoa certification in 2010. This was championed by SARO Agro-Allied Ltd, a cocoa exporter, and leading global cocoa processor, Archer Daniels Midland Company (ADM) (UTZ certified, 2013). They worked in partnership to achieve the certified status. Other exporters involved in certification in Nigeria are Armajaro, Continaf, Agro-Traders, Bolawole Nigeria Enterprises etc. The Federal Government Cocoa Transformation Agenda (CocTA) in Nigeria in which certification is a component is aimed at boosting production improve livelihood and create jobs for farmers and other stakeholders (Babatunde, 2012).

The essence of cocoa certification is for sustainability of the cocoa value chain. It improves beans quality and help farmers practice Good Agricultural Practices. Paschall and Seville, (2012) reported that it provides social benefits such as better farmer skills and knowledge, more children in education through awareness-raising and the prohibition of child labour. Certification brings better terms of trade and ensures trust in the origin of cocoa product. It increases cocoa yield for farmers and ensures traceability of cocoa beans from the source (The Nation Newspaper, 2013). Through certification, farmers are benefiting from comprehensive training programmes that assist them in their farming activities. It helps stakeholders in the safe handling and storage of chemical inputs which promotes good health. Certification serves as an effective tool for helping farmers organize as a group and plan together for the future (Hafid, et al 2013). 
Perception as used in this context is a psychological term that guides farmers understanding in harnessing, processing and channeling relevant information towards fulfilling the perceiver's requirements (Rao and Narayana, 1998). For instance in 2010, the Dutch government together with private sector players, NGO's and development organizations signed a letter of intent where it explicitly announces the objective of having a $100 \%$ guaranteed sustainable cocoa consumption in the Netherlands by 2025 (ICCO, 2012). If producers have poor knowledge of certification, it will affect their preparedness to adopt and sustain it thereby impacting on global food security in the cocoa sub-sector.

The major objective of the study is to examine the perception of farmers about cocoa certification in the study areas. The specific objectives were to: examine cocoa farmers' selected socio-economic characteristics, investigate the awareness of farmers about cocoa certification in Nigeria, ascertain the perception of farmers towards certification of cocoa and ascertain if the CocTA of Nigerian government will encourage farmers to practice cocoa certification.

\section{Hypothesis}

It was hypothesized that there is no significant relationship between socio-economic characteristics and perception of farmers towards cocoa certification.

\section{Methodology}

A multi stage procedure was used in selecting Cross River and Osun States of Nigeria for the study due to certification training carried out in the two states. In each State, forty farmers were selected from two Local Governments Areas namely: Etung and Ikom in Cross River and Ilesa East and Obokun in Osun state. A purposive random sampling technique was used in selecting eighty cocoa farmers in all using interview schedule. A five point Likert scale comprising 20 statements of Strongly disagree, Disagree, Undecided, Agree and Strongly agree was used to measure perception.

The study collected information on cocoa farmers' selected socio-economic characteristics, farmers' awareness and perception about cocoa certification.

Descriptive statistics and Pearson product moment correlation (PPMC) were used in the analyses.

\section{Farmers' awareness of cocoa certification}

\section{Results and discussion}

Results in Figure 1 indicated that Majority of the farmers (87.5\%) were aware of voluntary standard cocoa certification notably UTZ certified and Rainforest Alliance. This result is in agreement with a pilot survey carried out by Hafid, et al (2013) that most of the respondents were aware of cocoa certification.

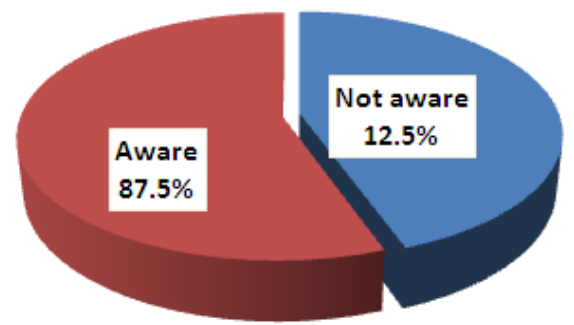

Figure 1: Farmers' awareness of cocoa certification

Source, Field survey, 2013

Cocoa certification training

In Table 1, 32.5\% of the farmers claimed to have received cocoa certification training from some exporters using UTZ certified label.

Table 1: Distribution of cocoa certification training by UTZ

\begin{tabular}{lll}
\hline Certification training & Frequency & Percentage \\
\hline Received training & 26 & 32.5 \\
Did not received training & 54 & 67.5 \\
Total & 80 & 100 \\
\hline
\end{tabular}

Source, Field survey, 2013 


\section{Farmers' believe in Government CocTA towards cocoa certification}

The results in Table 2 revealed that many $(67.5 \%)$ of the farmers believed that the Cocoa Transformation Agenda (CocTA) of Government will encourage them to be involved in certification process so as to produce certified cocoa. However, 27.5\% did not believe in the agenda. It implies that there are high hopes on the part of farmers that cocoa certification will motivate them in certification programme.

Table 2: Distribution of farmers' believe in Government CocTA towards cocoa certification

\begin{tabular}{lcc}
\hline Response & Frequency & Percentage \\
\hline Agree & 54 & 67.5 \\
Undecided & 4 & 5.0 \\
Disagree & 22 & 27.5 \\
Total & 80 & 100 \\
\hline Source, Field survey, 2013 &
\end{tabular}

Source, Field survey, 2013

\section{Perception statements towards cocoa certification}

Table 3 showed that the farmers perceived and ranked first; timely weeding, second long and proper cocoa fermentation for good quality with a mean of $4.68,4.55$ and 4.45 respectively. Cocoa pod sprayed with chemical will not affect products made from it and getting same price for cocoa beans not well fermented ranked lowest. Irrespective of their high rating of the statements, they did not know that chemical residue could affect beans from the pod.

Table 3: Mean scores and ranking of perception statements towards cocoa certification

\begin{tabular}{|c|c|c|c|}
\hline Statement & Mean & SD & Rank \\
\hline Timely weeding of cocoa farm is good for certification & 4.68 & 0.55 & 1 \\
\hline Fermentation of cocoa beans can be done for 5-6 days before drying & 4.55 & 0.79 & 2 \\
\hline Properly fermented cocoa beans improves aroma and quality & 4.45 & 0.86 & 3 \\
\hline Knapsack sprayer should be properly cleaned after use & 4.39 & 0.1 & 4 \\
\hline Belonging to farmers' cooperative body is relevant for group certification & 4.36 & 0.86 & 5 \\
\hline Cocoa certification enhances quality of beans & 4.20 & 0.85 & 6 \\
\hline Wearing protective clothing does not matter during spraying & 3.92 & 1.17 & 7 \\
\hline Pruning cocoa trees will reduce production & 3.85 & 1.25 & 8 \\
\hline Shortage of farm labour will affect cocoa certification & 3.78 & 1.24 & 9 \\
\hline Allowing children below 18 years to work in cocoa farm is not bad. & 3.74 & 1.00 & 10 \\
\hline I do not know the variety of cocoa planted in my farm & 3.66 & 1.22 & 11 \\
\hline Empty container of used chemical can be washed and re-used to store things at home & 3.56 & 1.28 & 12 \\
\hline It is better to bury used chemical containers on the farm than leaving it on the surface of the ground & 3.46 & 1.17 & 13 \\
\hline Cocoa certification does not encourage payment of premium & 3.43 & 1.24 & 14 \\
\hline Recommended cocoa chemicals are not available in the market & 3.40 & 1.39 & 15 \\
\hline Proper use of chemicals on cocoa is part of certification & 3.39 & 1.11 & 16 \\
\hline Certification of beans does not improve prices of cocoa & 3.38 & 0.83 & 17 \\
\hline Certification will not ensure sustainability of cocoa sub sector & 3.24 & 1.43 & 18 \\
\hline Spraying cocoa pod with chemical will not affect products made from cocoa & 3.00 & 1.47 & 19 \\
\hline The price of cocoa beans fermented for 2 days is the same as the ones fermented for 5 days & 2.86 & 1.48 & 20 \\
\hline Overall mean & 3.77 & & \\
\hline
\end{tabular}

Source, Field survey, 2013

\section{Summary of farmers' perception level scores about cocoa certification}

Table 4 shows that $52.5 \%$ of the farmers had low perception while $47.5 \%$ showed high perception level towards cocoa certification. It means that their knowledge needs to be improved to increase their opinion about certification.

Table 4: Summary of farmers' perception level scores about cocoa certification

\begin{tabular}{llll}
\hline Perception levels & Mean score & Frequency & Percentage \\
\hline High & $\geq 75.79$ & 38 & 47.5 \\
Low & $\leq 75.79$ & 42 & 52.5 \\
Total & & 80 & 100 \\
\hline Maxim
\end{tabular}

Maximum 96.0, Minimum 55.0, Standard deviation 9.47

Source, Field survey, 2013

\section{Correlation of socio-economic characteristics and farmers' perception in cocoa certification}

Correlation coefficient revealed that socio-economic characteristics: age $((-0.37)$ and farming experience $(-0.31)$ had a negative significant influence on the perception of farmers towards cocoa certification while farm size $(0.36)$ and yield $(0.24)$ showed a positive influence at probability $<0.05$ (Table 5). It means that as age and experience decreases, certification increases. Also, as farm size and yield increases, certification 
increases. In other words, the socio-economic variables of farmers could affect their perception about certification.

Table 5: Correlation of socio-economic characteristics and perception of farmers towards cocoa certification

\begin{tabular}{lll}
\multicolumn{3}{c}{$(\mathrm{n}=80)$} \\
\hline Variables & Correlation coefficient & Probability \\
\hline Age & $-0.37^{* *}$ & 0.001 \\
Farming experience & $-0.31^{* *}$ & 0.050 \\
Farm size & $0.36^{* *}$ & 0.001 \\
Yield & $0.24^{*}$ & 0.030 \\
\hline
\end{tabular}

Source, Field survey, 2013

\section{Conclusion and recommendation}

Socio-economic variables had reasonable influence on farmers' perception of cocoa certification. It implies that these are relevant factors which CocTA and other stakeholders can explore to ensure sustainable cocoa production. There was low perception towards cocoa certification among farmers. Training of more farmers on cocoa certification in the study areas is advocated to consolidate their views, knowledge and practice.

\section{References}

[1]. Babatunde, J., 2012. Cocoa Transformation: Can new team lift Nigeria's cocoa production? Available from www.vanguardngr.com/2012/02/cocoa-transformation-can-new-team-lift-nigerias-cocoa-production/ on 07/o9/ Accessed on $19 / 09 / 12$.

[2]. International Cocoa Organization (ICCO), 2012. Cocoa certification: Study on the costs, advantages and disadvantages of cocoa certification. A report on cocoa certification, a KPMG advisory.October, 2012.

[3]. ICCO, 2013.International workshop on cocoa certification. The multiplicity of standards in the cocoa market: finding a way forward. Cocoa certification conference held in Yaounde Cameroon. Available fromhttp://www.icco.org/about-us/internationalcocoa-agreements/doc_download/440-international-workshop-on-cocoa-certification-cameroon-june-2013.html. Accessed 8-042013.

[4]. Hafid, H., Neilson, J., Mount, T. and McKenzie, F., 2013. Sustainability Impact Assessment of a Certification Scheme in the Indonesian Cocoa Industry: 2012 Pilot Survey Results. Discussion Paper released in March 2013 by University of Sydney, Australia. Pp. 1-5.

[5]. Paschall, M. and Seville, D. ,2012. Certified cocoa : scaling up farmer participation in West Africa. Available fromhttp://pubs.iied.org/pdfs/16034IIED.pdf. Accessed 8-04-2013.

[6]. Rao, V.S.P. and Narayana, P.S., 1998. Organisational theory and behaviour. Delhi: Konark publishing company. Pp. 329-330.

[7]. The Nation Newspaper, 2013. How to make Nigeria's cocoa more attractive. Available from http://thenationonlineng.net/new/business/agriculture/how-to-make-nigerias-cocoa-more-attractive/Accessed 04-04-2013.

[8]. UTZ certified, 2013. UTZ Certified announces first Nigerian cocoa certification. Available from https://www.utzcertified.org/fr/sallederedaction/communiquesdepresse/2075-utz-certified-announces-first-nigerian-cocoacertification-in-conjunction-with-adm-and-saro-agro-allied-ltd- Accessed 27-03-2013. 